Berkeley Law

From the SelectedWorks of Robert Cooter

June, 1994

The Logic of Power in the Emerging European Constitution: Game Theory and the Division of Powers

Robert Cooter

Josef Drexl 


\title{
The Logic of Power in the Emerging European Constitution: Game Theory and the Division of Powers*1
}

\author{
ROBERT COOTER ${ }^{* *}$ \\ University of California at Berkeley, Berkeley, California 94720
}

AND

JOSEF DREXL ${ }^{* * *}$

Max-Plank Institul, Siederstrasse 3, 81675, Munich, Germany

The major institutions of government in the European Community are the Council of Ministers, the Parliament, the Court of Justice, and the Commission. The initial treaties prescribed a legislative process in which the Commission proposed, the Council enacted, and the Court interpreted. The Council enjoyed the exclusive power of legislation, and most of its enactments required unanimity. In contrast, the Parliament had, at most, a right to be consulted about legislation. In effect, the institutions of European government originally provided a framework for cooperation among ministers of the sovereign states.

From this beginning, the European Community has evolved gradually towards a democratic government. Specifically, majority rule is replacing unanimity in the Council, and the role of Parliament is increasing towards full partnership in the legislative process. Legislation now must follow majoritarian, bicameral procedures on some issues, and the scope of these issues will presumably widen. The obvious consequence of these changes is a decrease in the power of the Council and an increase in the power of Parliament. We use game theory to prove the not-so-obvious fact that majoritarianism in the Council increases the power of the Commission and, in the long run, decreases the power of the Court, whereas bicameralism has the opposite effect. Our analysis suggests a revaluation of the implementation of democracy in Europe.

To be more precise, there are four procedures for European legislation that differ according to the extent that the Council must involve Parliament in making law. The procedures, arranged in order of increasing involvement of Parliament, are called unilateral, consultation, cooperation, and co-decision. A change from consultation to cooperation on an issue, and a change from cooperation to co-decision, obviously

\footnotetext{
-This paper is dedicated to Wolfgang Fikentscher, teacher and friend, in celebration of his 65th birthday.

**Professor of Law, University of California at Berkeley. Ph.D. Economics, Harvard University. ***Academic Assistant, University of Munich, Institute for European and International Econornic Law. JD 1988.
Dr. jer. (Ph.D.) 1990 (Munich), LL.M. 1993 (Berkeley).
}

'This paper was written for the Comparative Law and Economics Forum, Brussels, Betgium, June 1993. We benefitted from comments by Torsten Persson and members of the workshop at the Institute for International Economics, Stockholm University. 
and Parliament can, by following the appropriate procedure described, enact or reject proposals. Alternatively, the Council and Parliament can ask the Commission to revise the proposal. If the Commission agrees, the revised proposal can be enacted or rejected like any other proposal by the Commission. If the Commission refuses to revise its proposal, the amended proposal can still be enacted. However, enacting an amended proposal over the Commission's objection requires unanimity in the Council. Unanimity in the Council is the procedure for amendment without the Commission's consent. ${ }^{9}$

The European Parliament has been directly elected by the citizens of the member states since 1979. Parliament initially had two main powers, which it retains. Its approval is needed for the adoption of the budget (Art. 203, EEC-Treaty), and it may adopt a motion of censure resulting in the resignation of the Commission (Art. 144, EEC-Treaty).$^{10}$ In addition, Parliament enjoys a right to be consulted by the Council on some legislative issues, but not others.

In the history of the European Community, the basic structure of the legislative. procedure laid down in the establishing treaties has been amended twice. Amendments are prescribed in the Single European Act of 1986 and the so-called Maastricht Treaty on European Union of 1992. The Single European Act introduced the new procedure of cooperation (Art. 149, EEC-Treaty, now Art. 189c, EC-Treaty). For issues to which this procedure applies, the Council must cooperate with Parliament to enact legislation, not merely consult with Parliament." Under the procedure of cooperation, a proposal that enjoys a qualified majority on the Council does not become law until it wins a majority in Parliament. If the proposal falls short of a majority in Parliament, a unanimous vote of the Council is required to override Parliament and enact the proposal.

In a further move towards majority rule, the Maastricht Treaty introduced yet another procedure, called co-decision (Art. 189b, EC-Treaty). Co-decision strengthens the power of Parliament to reject proposals adopted by the Council. Under the new procedure, Parliament's final rejection of a proposal on certain issues cannot be overcome by the Council, even if the Council is unanimous. Consequently, Parliament and Council both have to agree on a proposal to make law on these issues. Co-decision will be implemented after the Maastricht Treaty takes effect. ${ }^{12}$

Thus the European constitution specifies four legislative procedures: unilateral (Council legislates), consultation (Council consults Parliament), cooperation (Council obtains Parliament's cooperation), and co-decision (Council and Parliament both decide). Different procedures apply to different issues. For example, agreements concerning international trade are decided unilaterally by a qualified majority in the Council (Art. 113, EC-Treaty). When an issue demands Community action, but the EC-Treaty does not explicitly authorize acting, the procedure of consultation applies

\footnotetext{
To illustratc, suppose that a proposal for legishation advances under the procedure of cooperation and Parliatnent proposes an amendment. The preposal for an amendment goes to the Commission, which first drafted the legistation. The Commission must decide whether to accept or reject the amendment. If the Commission acoepts the amendment, the amended proposal can be enacted by a qualified majority in the Council. If, however, the Commission rejects the amendment, its enactment requires unanimity in the Council.
}

The motion of censure has never been used.

'The dhange was required by the Single European Act of 1986.

'The Maastricht Treaty became effective on 1 November 1993. 
(Art. 235, EC-Treaty)..$^{19}$ The harmonization of national laws for the establishment of the Internal Market followed the procedure of cooperation under the Single European Act. The Maastricht Treaty retains cooperation for some issues of harmonization (Art. 189c, EC-Treaty) and replaces cooperation with co-decision on other issues of harmonization (Art. 100a, EEC-Treaty). ${ }^{\text {14 }}$

Movement from unanimity to consultation, from consultation to cooperation, and from cooperation to co-decision represents a progression from state sovereignty towards bicameral, majoritarian legislation. Movement along the progression is typically described as progress towards European democracy. The movement is described as democratization for two reasons. First, unlike Parliament, the Council represents national governments. ${ }^{15}$ Second, whereas Parliament proceeds by majority rule, a minority of the national governments in the Council can block legislation favored by a majority. The EC has evolved piecemeal towards democracy by shifting issues further along this progression, but evolution is uneven because issues determine procedures:

For the purpose of our article we have to simplify reality. The Commission has the exclusive right to propose legislation. Council and Parliament share power to enact proposals, although the role of each varies with the procedure applicable to the issue. The ultimate power to interpret legislation belongs to the Court. We summarize these simplifications in three propositions.

Stylized legislative powers

A. Propose: The Commission has exclusive power to propose legislation.

B. Enat: Council and Parliament have exclusive power to enact proposals by the Commission.

C. Interpretation: The Court of Justice has final power to interpret legislation.

Having stylized the three legislative powers, we now stylize the EC's four legislative procedures. First, under the unilateral procedure, the Council can enact legislation on its own, by unanimity or qualified majority. Under unanimity, a proposal by the Commission is only adopted with approval by all member states. Under qualified majority, the proposal is enacted when the pro-rated votes reach the number stipulated by treaty.

Now we turn from the unilateral procedure to consultation. The European Parliament had a right to be consulted on some, but not all, issues. Unlike the unilateral procedure, the right to be consulted gives Parliament the power to delay enactment. The power of delay is, in economic terms, the power to impose transaction costs. Thus the right of consultation enables Parliament to discourage proposals that it disfavors by increasing the transaction costs to the Council of enacting them.

Our model does not explicity analyze transaction costs. Consequently, for purposes of this paper, we proceed as if the power of consultation were no power at all. We

\footnotetext{
19 Note that the Maastricht Treaty substitutes "EC" (Eutropean Community) for "EEC" (European Economic Community) in the rame of the Treaty.

'This is a change from the Art. 100, EEC-Treaty, which requires unanimity on the Council for legislation harmonizing national laws.

15 In this respect, the Parlianent is analogous to the U.S. House of Representatives and the Council is analogous to the U.S. Senate, which originally represented the states who joined cogether to create the United States.
} 
recognize that a completely satisfactory analysis of the logic of legislative power in Europe must model transaction costs explicitly, which in turn involves more complexity and detail than found in this paper. Similarly, we do not analyze many important institutional details, such as the committees by which the Commission, Council, and Parliament interact.

The third procedure, cooperation, applies to certain issues for which the Council proceeds by qualified majority. Under this procedure, a proposal that receives a qualified majority in the Council gets forwarded to Parliament. If the proposal receives a majority in Parliament, it becomes law. ${ }^{16}$ If the proposal does not receive a majority in Parliament, it does not become law unless enacted by a unanimous Council. Hence Parliament has the power to change the voting rule in the Council from qualified majority to unanimity. Consequently, a qualified majority in the Council must cooperate with Parliament to enact a proposal, rather than merely consulting Parliament. ${ }^{17}$

Finally, we turn to the new procedure called co-decision. Under this procedure, Parliament's final rejection of a proposal on certain issues cannot be overcome by the Council. ${ }^{18}$ Consequently, Parliament and Council both have to agree on a proposal to make law on these issues.

We may summarize these observations about alternative procedures for enacting European legislation:

Stylized legislative procedures

(1) Unilateral: This procedure has two forms.

Unanimity: The Commission has exclusive power to propose. The Council can adopt or amend the proposal by unanimous vote. If unanimity is not reached, the proposal is rejected.

Qualifred Majority: The Commission has exclusive power to propose. The Council can adopt by qualified majority. Otherwise, the proposal is rejected.

(2) Consultation: Same as unilateral, except Partiament has the right to be consulted.

(3) Cooperation: The Commission has exclusive power to propose. The Council can adopt by a qualified majority and amend by unanimity. If, however, Parliament rejects the proposal, the Council can only adopt by unanimity.

(4) Co-decision: The Coramission has exclusive power to propose. Adoption requires approval of the Council by a qualified majority and approval of Parliament by a majority.

\footnotetext{
${ }^{15}$ If Parliament does not react within three months after receiving the proposal, silence counts as approval.

1'The rules on cooperation in Art. 189c, EC-Treaty are very complex. We have only presented the basic eletnents necessary for our analysis. In fact, there are two readings in Parliament. Before the proposal goes to the Council. the Parliament is consulted (first reading). Then the Council adopts a "common position." In the second reading. Parliament can either approve, reject, or propose amendments.

${ }^{\text {LAAt }}$ 189b, EC.Treary. Again, this is a simplification of complex rules. Rejection of the common position by Parliament in the second reading leads to the establishment of a Conciliation Committer with representatives of both the Councit and Parliament. The Commission takes part in the debates, works as a mediator between Council and Parliament, but has no right to vote. The Conciliation Committee may propose a common text that even amends the initial proposal of the Commission. Adoption requites qualified majority in the Council and majority of the representatives of Parliament. If no common text is agreed upon, the Council may adopt the common position by qualified majority. But Parliament has power to reject the common position again in a third reading by a majority of its constituent members. In this case the common position will not be enacted.
} 


\section{The General Model}

We have sketched the powers and procedures of European legislation. Now we explain how the latter affects the former. We define the discretionary power of an institution as its ability to get the legislation that it wants. An institution's discretionary power increases when it can get more of the legislation that it wants. Before developing our formal models, we sketch briefly how alternative procedures affect the discretionary power of the Commission and the Court.

The Commission has the exdusive power to propose legislation. Some of its proposals will be enacted and others will be rejected or amended. The Commission has more discretionary power when it can choose among a larger range of alternatives from which to frame proposals that will be enacted into law. Consider how the discretionary power of the Commission changes with the procedural nules for enacting legislation. The unilateral procedure, or the procedure of consultation, permits the Council to enact proposals on its own, regardless of Parliament's opposition. Under the unilateral procedure, the Council enacts proposals under a unanimity rule or a qualified majority rule. The change in procedure from unanimity to qualified majority in the Council increases the power of the Commission. The power of the Commission increases because it only needs a qualified majority in the Council to enact its proposals. ${ }^{19}$

In contrast, the change from consultation to cooperation, and from cooperation to co-decision, decreases the power of the Commission. Its power decreases because it must anticipate objections by two bodies (Council and Parliament) when proposing legislation. The Commission has a smaller range of alternatives from which to frame proposals that will actually become law.

Now we turn from the Commission to the Court. An increase in the stock of Iegislation results in more litigation, which gives the Court more opportunity to make law by interpreting it. However, fresh legislation can be enacted to repeal judicial interpretation of existing law. An increase in the power to repeal judicial interpretation by fresh fegislation decreases the power of interpretation. Consequently, a distinction must be drawn between the stock and flow of legislation in Europe. The change from unanimity to qualified majority under the procedure of consultation increases the Commission's power to propose legislation, which increases the stock of legislation for the Court to interpret and decreases the scope of interpretation invulnerable to repeal by fresh legislation. The first effect is stronger in the short run and weaker in the long run. Thus Council majoritarianism decreases the discretionary power of the Court in the long run. Conversely, the change from the procedure of consultation to cooperation, or from cooperation to co-decision, increases the Court's discretionary power of interpretation and decreases the Commission's power to propose legislation.

To prove the arguments in the preceding section, we will sketch a general model and then apply it to Europe. We begin with the assumptions of the general model. First, we assume that decisions by institutional decision makers reveal a preference ordering.

Specifically, we assume that decision-making procedures in the Commission, Council, Padiament, and Court yield stable preferences attributable to them. According to this assumption, the paradoxes of voting are overcome by appropriate mechanisms of collective choice. ${ }^{20}$ Note that the preferences of an institution depend upon its

${ }^{19}$ Under this procedure, amendment of a proposal by the Commission still requires unanimity in the Council.

soor example, agenda setting determines the outcome when there is no Condorcet winner. 
decision-making procedures. For example, the Council will reveal different preferences under the procedure of unanimity than under the procedure of qualified majority.

Second, we assume that the executive (Commission), and no one else, has the exclusive power to propose legislation, and the executive can present the legislature with a take-it-or-leave-it proposal.." Raw power is exercised when the Commission makes take-it-or-leave-it proposals. In reality, political actors bargain together to achieve shared goals. Specifically, the Commission usually bargains with Council and Parliament, rather than making take-it-or-leave-it offers. However, raw power guides and directs bargaining. Specifically, raw power typically defines the starting points from which the parties make concessions. Consequently, our analysis will provide the foundation for a bargaining model, which would be more accurate and far more complex.

This assumption, which implies that the executive can "commit" to a particular proposal, is close to the truth in many circumstances, and far from it in some ochers. ${ }^{22}$ The motivation for the assumption is not realism but tractability in the initial stage of model building. This assumption eliminates strategic behavior between the executive and legislature, including the need for bargaining. When this assumption is true, the legislature has a choice between the executive's proposal and the status quo. Consequently, the legislature will enact any proposal it prefers to the status quo, and reject any proposal that it likes less than the status quo. ${ }^{23}$

The discretionary power of the executive is measured by the set of possible proposals that the legislature will enact. Consequently, the executive's discretionary power increases when the legislature prefers more proposals to the status quo, and the executive's discretionary power decreases when the legislature prefers fewer proposals to the status quo.

The number of proposals that the legislature prefers to the status quo depends upon its decision-making procedures. A procedure requires a weaker majority to enact legislation if enactment requires fewer members to vote for the bill. For example, a change from unanimity to qualified majority, or from qualified majority to simple majority, requires a weaker majority to enact legislation. A procedural change requiring a weaker majority to enact legislation causes the legislature to prefer more proposals to the status quo. Now we can state our first general result:

PROPOSITION I (majoritarianism): A procedural change requiring a weaker majority to enact legislation increases the discretionary power of the executive to propose legislation.

Legislatures typically consist of one or two houses." In some systems the second house has limited power, such as the power to consult or slow down legislation. In

\footnotetext{
2'This approach has been taken with respect to bilts reported out of committees in the U.S. Congress under the "dosed rule," in which the legislature must accept or reject the committee's bill but cannot amend it. See John Ferejohn, Pork Barrel Potitics (Stanford University Press, Stanford, 1974).
}

"This assumption is dose to the truth when (i) transaction costs preclude the Commission from amending its proposals, or (ii) the Commission takes a "hand line" on various proposats. This assumption is far from the truth when continuous discussion between Commission and Council shape the proposal eventually offered by the Commission.

${ }^{2}$ Notice that all the bargaining surplus will go to the executive, thus exaggerating his discretionary powet.

"Some legislatures have more than two houses, such as Taiwan. 
other systems, both houses have to approve before a proposal becomes law; so the two houses have roughly equal power. The legislature prefers more proposals to the status quo when enactment requires approval by only one house rather than two houses. Now we can state our second general result:

PROPOSITION 2 (bicameralism): A procedural change requining two houses of the legislature, rather than one, to approve a proposal before it becomes law, decreases the discretionary power of the execulive to propose legislation.

Now we turn from the executive to the judiciary. A faster pace of legislation increases the stock of laws for the Court to interpret. We assert without proving that a larger stock of legislation increases the power of interpretation. Indeed, the shift to Council majoritarianism apparently resulted in an increase in European legislation and the litigation of it. ${ }^{25}$ After a proposal is enacted, the court must interpret legisiation as cases arise. If the legislature were precise in drafting the law, and if the court were the faithful servant of the legislature, the court would interpret the law exactly as drafted by the legislature. However, the drafting of the proposal may not be precise, or the court may not be the faithful servant of the legislature. Whatever its reasons, an independent court can make law or change it by interpretation. Our third assumption is the independence of the judiciary. Judges are independent when their income, power, and tenure do not depend upon their decisions. ${ }^{26}$

When the court makes law or changes it by interpretation, the judge-made law may be repealed by fresh legislation. The court has discretionary power within the range of interpretations that will not provoke legislative repeal. The discretionary power of the court ends where its interpretations provoke legislative repeal. An interpretation cannot be repealed by fresh legislation if no alternative exists that the executive would propose and the legislature would enact. No viable alternative exists if no potential proposal is preferred to the court's interpretation by all the decision-makers who must propose and enact fresh legislation. No potential proposal is preferred by all the decision-makers who must propose and enact fresh legislation so long as the court's interpretation is Pareto efficient relative to their preferences. Now we can state our last general result:

PROPOSITION 3: The court's discretionary power of interpretation over a given stock of laws corresponds to the set of possible laws that are Pareto efficient relative to the preferences of the decision-makers who must propose and enact fresh legislation.

We will show that a procedural change requiring a weaker majority to enact legislation typically decreases the legislature's Pareto set, and thus decreases the discretionary power of the court. Conversely, a procedural change requiring proposals to be enacted by two houses of the legislature, rather than one, typically increases the legislature's Pareto set, and thus increases the discretionary power of the court. Thus majoritarianism weakens the discretionary power of interpretation in the long run, and bicamer- 
alism strengthens it. In this respect, the power to interpret is the opposite of the power to propose.

\section{Maximizing Model}

We develop the same arguments as in Part III using a standard economic model from collective choice theory. ${ }^{27}$ Economists usually assume that decision-makers order alternatives from better to worse and choose the best available alternative. We assume that the preferences of the Commission, Council, and Commission are independent. ${ }^{28}$ To keep the representation simple, we will consider choice in only one dimension.

We begin by explaining the basic model with the help of a diagram. The horizontal line in Figure 1 represents a dimension of political choice along which the alternatives can be ranked from "small" to "large." To illustrate, the dimension might be the amount of pollutants that the law allows cars to emit, the strength of the health warning that the law requires on tobacco products, or the duration of copyright protection.

The point labeled $L$ in Figure 1 represents the most preferred point by the legislature. The farther the decision moves away from $L$, the less preferred it is by the legislature. Two other points on the graph are salient for the legislature. The point labeled 0 represents the status quo, which will prevail in the absence of legislation. As the selected point moves from 0 towards $\mathrm{L}$, the legislature likes the outcome more. As the selected point continues moving past $L$ towards a larger number, the legislature likes the outcome less. The point $\mathrm{L}(0)$ corresponds to a choice that is so large that the legislature is indifferent between 0 and $L(0)$. Beyond $L(0)$, the legislature would rather have 0 .

Following the stylized facts about power in Europe, assume the executive has the exclusive power to propose legislation. Also assume the legislature has the exclusive power to enact proposals by majority vote. In a general model, the legislature would take into account the fact that rejecting one proposal may force the executive to

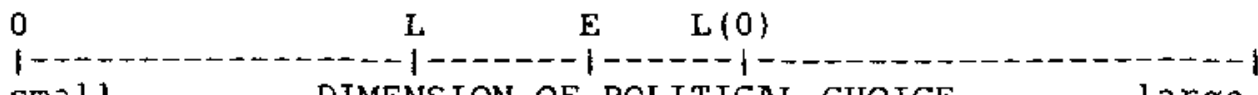

sma 11

DIMENSION OF POLITICAL CHOICE large

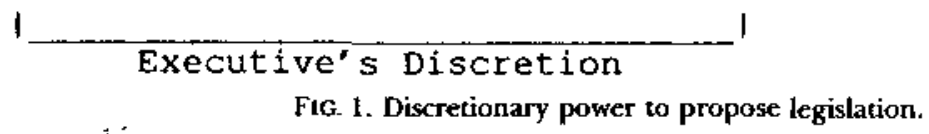

\footnotetext{
${ }^{27}$ For example, see J. Ferejohn and B. Weingast, "A Positive Theory of Statutory Interpretation," 12 International Reviet of Law and Economics 263-279 (1992). J. Ferejohn and B. Weingast, "Limitation of Statutes: Strategic Statutory Interpretation," 80 Georgetown Lew Journal 565-582 (1992). For application of this reasoning to the Europeant Community, see George Tsebelis, "The Power of the European Partiament As a Conditional Agenda Setter," 88 American Potitical Science Reviaw 138-142 (1994). For related papers see Andre Moravcsik, "Why the European Community Strengthens the State: Domestic Politics and Intemational Cooperation (presented at the Conference of Europeanists, Chicago, April, 1994), and Anne-Marie Burley and Walter Matti, "Europe Before the Court: A Political Theory of Legal Integration," 47 Intemational Onganizntion 41-76 (1993).
}

wi"Independent" meaus that one party does not want something just because the other party wants it. For example, we assume that a national government which appoints a judge to the Court does not order the judge to do whatever 
propose another. Consequently, the executive and legislature might engage in explicit or implicit bargaining. Various bargaining strategies are possible on the part of executive and legislature.

To keep the model simple, we eliminate these strategic possibilities. Instead, we assume that the executive can successfully "commit" to a particular proposal and thus present the legislature with one final take-it-or-leave-it choice. Under these assumptions, a proposal by the executive presents the legislature with a choice between the proposal and the status quo. ${ }^{29}$

Consequently, the legislature will enact any proposal that a majority of its members prefers to the status quo, and reject any proposal that they like less than the status quo. ${ }^{* 0}$ In terms of Figure 1, the legislature will enact any proposal that falls in the interval between 0 and $L(0){ }^{31}$ The discretionary power conveyed upon the executive by its exclusive power to propose legislation is given by the set of points $[0, L(0)]$, as : indicated in Figure 1.

Now we turn from the power to propose legislation to the power to interpret it. Suppose the executive's most preferred point on the dimension of choice is indicated by $E$ in Figure 2. Notice that $E$ lies within the range of the executive's discretionary power. Consequently, the executive proposes $\mathbf{E}$ and the legislature enacts it.

If the judiciary were the faithful agent of the legislature, the court would interpret the legislation as standing for point $\mathrm{E}$, neither more nor less. However, let us consider the extent to which the court could depart from this role by acting as an independent power. How far can the judiciary depart from point $E$ when interpreting the law without provoking repeal by fresh legislation?

Repeal by fresh legislation will occur if the judiciary's interpretation corresponds to a point on the policy dimension such that the executive and the legislature both prefer another point. To illustrate, if the interpretation lies to the left of $\mathrm{L}$, both the legislature and the executive will prefer fresh legislation enacting point L. Similarly, if the interpretation lies to the right of $\mathbf{E}$, both the legislature and the executive will prefer fresh legislation enacting point $E$. Consequently, the judiciary lacks the power to interpret existing law to mean any point below $L$ or above $E$.

Conversely, the judiciary has the power to interpret existing law to mean any point above $\mathrm{L}$ and below $\mathrm{E}$, as indicated in Figure 2. To illustrate, suppose the judiciary

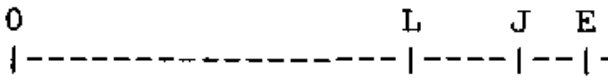

sma11.

DIMENSION OF POLITICAL CHOICE large

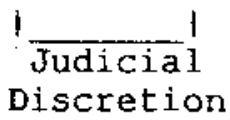

FIG. 2. Discretionary power to interpret legislation.

\footnotetext{
${ }^{29}$ This assumption may not be so far from the truth because (i) transaction costs sometimes preclude the Commission from amending its proposals, or (ii) the Commission tnay take a "hard line" on various proposals.
}

${ }^{50}$ Notice that all the bargaining surplus will go to the executive, thus exakgerating his discretionary power. 
interprets the existing law to correspond to point $j$ in Figure 2. The executive prefers $J$ to any smaller point. Consequently, the executive is only willing to make a new proposal to the right of $J$. However, the legistature prefers $J$ to any larger point. Consequently, the legislature is only willing to enact a new proposal to the left of $\mathrm{J}$. No alternative to $\int$ exists that the executive will propose and the legislature will enact, so interpretation J cannot be repealed by fresh legislation.

For any point in the interval $[\mathrm{L}, \mathrm{E}]$, no alternative exists that is preferred by the legislature and the executive. Consequently, the interval $[L, E]$ represents the set of Pareto efficient points relative to the preferences of the legislature and executive. In general, the discretionary power of judicial interpretation is given by the Pareto set for the parties holding independent vetoes over fresh legislation.

Now we apply this model to Europe. According to the stylized facts about the European constitution, the role of the "executive" in Figures 1 and 2 is performed. by the Commission, the role of the "legislature" is performed by the Council and Parliament, and the role of the "judiciary" is performed by the Court. The only difference between the stylized facts about Europe and the model in Figures 1 and 2 is that the European legislature has two houses and one of them does not follow majority rule when enacting legislation. We will modify the model to accommodate these facts.

\section{A. Unanimity}

Under the unilateral procedure, Parliament has no formal role in legislation. Under the procedure of consultation, Parliament's only formal power over legislation is to be consulted, which creates the effective power to slow down legislation. To keep our model simple, we assume that this is no power at all (zero transaction costs), so that the unilateral procedure is equivalent to the procedure of consultation.

These two procedures have two different forms, depending upon whether the exclusive power of the Council to enact proposals requires unanimity or a qualified majority. We first explain the form requiring unanimity. Assume that everyone on the Council prefers a little action rather than none. As we move from $\mathbf{0}$ to the right, everyone on the Council prefers the change at first. ${ }^{32}$ However, a point will soon be reached where someone on the Council objects to moving further to the right. Indicate this point by $U_{\min }{ }^{33}$ As we move still further to the right, a point will be reached where someone on the Council prefers 0 to it. Indicate this point by $\mathrm{U}(0)$.

Assume the Commission presents the Council with take-it-or-leave-it proposals. The Council will unanimously enact any proposal by the Commission that is above $\mathbf{U}_{\text {min }}$ or below $U(0)$. Someone on the Council will reject any proposal above $U(0)$. Proposals above 0 and below $U_{\text {min }}$ will be changed to $U_{\text {min }}$, because everyone on the Council prefers this point to the proposal. Consequently, the Commission's zone of discretion under a unanimity rule in the Council is given by the interval $\left[U_{\min }, U(0)\right]$, as depicted in Figure 3.

Now consider the discretionary power of the Court to change the law by interpretation. A proposat from the Commission to repeal the Court's interpretation will be enacted if everyone on the Council prefers the Commission's proposal to the Court's 


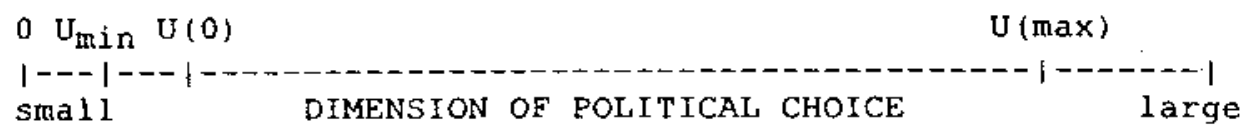

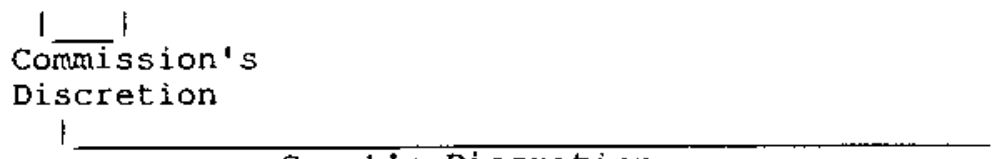

Court ${ }^{\top} \mathbf{s}$ Discretion

FIc. 3. Power under the unanimity procedure.

interpretation. Conversely, the Court's interpretation cannot be repealed if the Com:mission, or someone on the Council, prefers it to any alternative.

As we move from 0 to the right, everyone on the Council prefers the change at first, but a point is soon reached, labeled $U_{\text {ming }}$, where someone on the Council objects to moving further to the right. If the Court's interpretation is below $\mathrm{U}_{\min }$, everyone on the Council would prefer $\mathrm{U}_{\min }$ instead of the Court's interpretation. Consequently, this interpretation could be repealed by legislation.

Similarly, as we start from the largest point on the dimension of choice and move gradually to the left towards smaller values, everyone on the Council prefers the change at first, but a point is soon reached where someone on the Council objects to moving further to the left. Label this point $\mathrm{U}_{\text {max }}{ }^{\text {"3 }}$ If the Court's interpretation is above $U_{\max }$, everyone on the Council would prefer $U_{m a x}$ instead of the Court's interpretation. Consequently, this interpretation could be repealed by legislation.

If the Court's interpretation is below $\mathrm{U}_{\max }$ and above $\mathrm{U}_{\min }$, someone on the Council will prefer the Court's interpretation rather than an alternative to the left or to the right. ${ }^{35}$ Consequently, someone on the Council will veto any proposal to repeal the Court's interpretation by fresh legislation. The interval between $U_{\min }$ and $U_{\max }$, denoted $\left[U_{\min }, U_{\max }\right]$, thus represents the range of interpretations that the Council is unwilling to repeal.

If the Court's interpretation is inside $\left[\mathrm{U}_{\text {max }}, \mathrm{U}_{\text {max }}\right]$, it cannot be repealed by any proposal made by the Commission. It is most likely that the Commission's most preferred point is inside $\left[U_{-i m}, U_{m a x}\right]$, in which case $\left[U_{m i x}, U_{\max }\right]$ represents the Court's discretionary power of interpretation, as depicted in Figure 3. However, it is also possible that the Commission's most preferred point is outside $\left[\mathrm{U}_{\min }, \mathrm{U}_{\max }\right]$, in which case the Court's discretion is even greater. To illustrate, suppose the Commission's most preferred point, denoted $\mathrm{E}$, is larger than $\mathrm{U}_{\text {mar. }}$. Consequently, if the Court's interpretation is above $U_{m x}$ and below $E$, the Commission will not propose its repeal. Thus the Court's discretionary power of interpretation is represented by [ $\mathbf{U}_{\min }, \mathbf{E}$ ]. In general, the Court's discretionary power of interpretation can be written $\left[\min \left(E, U_{\min }\right)\right.$, $\left.\max \left(E, U_{\max }\right)\right]$.

${ }^{M_{U_{-}}}$is the most preferred point of the member of the Council who is farthest right on the dimension of choice.

"We implicitly assume that everyone's preferences are single peaked on the dimension of choice. 


\section{B. Qualified Majority}

Next consider the unilateral procedure, or the procedure of consultation, in the form where the Council has exclusive power to enact proposals by a qualified majority. Recall that as we move from 0 to the right, everyone on the Council prefers the change at first, but the point $U_{m i}$ is soon reached where someone objects to moving further to the right. As we continue moving to the right, we reach a point where someone prefers 0 to it. As we move still further to the right, a point will be reached eventually where a qualified majority on the Council prefers 0 to it. Let $Q(0)$ in Figure 4 denote this point.

A qualified majority on the Council will enact any proposal by the Commission that is above 0 or below $Q(0)$. However, a unanimous Council would prefer $\mathbf{U}_{\min }$ to any point below $U_{\text {min. }}$. Consequently, the Commission's zone of discretion is given by the interval $\left[U_{m_{i n}}, Q(0)\right]$, as depicted in Figure 4.

Now we turn to the Court's discretionary power. As we move from 0 to the right, $\cdots$ everyone on the Council prefers the change at first and then some members begin to object. As we move further to the right, more and more members of the Council object. Defined the complement of a qualified majority as the minimum number of votes that prevents a proposal from obtaining a qualified majority ${ }^{56}$ Let $Q_{\min }$ denote the point where the complement of a qualified majority objects to further moves to the right. ${ }^{37}$ Similarly, if we start from the largest point on the dimension of choice and move gradually to the left towards smaller values, everyone on the Council prefers the change at first, but a point is soon reached where the complement of a qualified majority on the Council objects to moving further to the left. Label this point $Q_{\max }{ }^{38}$

If the Court's interpretation is below $Q_{\text {miti }}$, a qualified majority on the Council would prefer $Q_{\min }$ instead of the Court's interpretation. Consequently, the Commission could
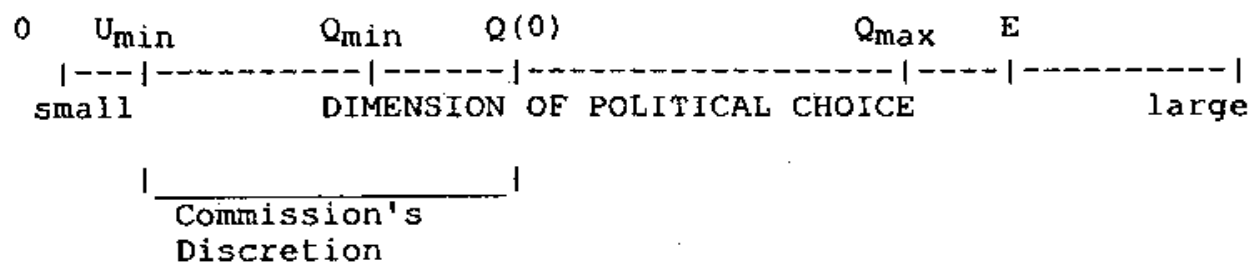

Discretion

Court's Discretion

Fic. 4. Power under the qualified majority procedure.

\footnotetext{
"Recall that a qualified majority is currently 54 out of 76 votes, so the complement is 23 votes. In general, the complement of $Q$ for $N$ voters equals $N-Q+1$.

${ }^{57}$ Order each member of the Council according to his or her most preferred point on the dimension of choice. Weight each member's preferences by his or her number of votes. Moving from left to right, $\mathrm{U}_{-}$is the most preferred point of the first member to be reached such that the nost preferred points of members commanding at least 23 votes lie to the left.
}

storder cach member of the Council according to his or her most preferred point on the dimension of choice. Weight each member's preferences by his or her number of votes. Moving from right to lef, $U_{\max }$ is the most preferred point of the first member to be reached such that the most preferted points of members cotnmanding at least 23 votes lie to the right. 
propose $Q_{\min }$ and it would be enacted. If the Court's interpretation is above $Q_{\operatorname{mix}}$, a qualified majority on the Council would prefer $Q_{\max }$ instead of the Court's interpretation. Consequently, the Commission could propose $Q_{m x}$ and it would be enacted. However, if the Court's interpretation is below $Q_{\max }$ and above $Q_{\min }$, a complement to a qualified majority on the Council will prefer the Court's interpretation rather than an alternative to the left or to the right. Consequently, a complement to a qualified majority on the Council will veto any proposal to repeal the Court's interpretation by fresh legislation. The interval $\left[Q_{\min }, Q_{\max }\right]$ thus represents the range of interpretations that the Council is unwilling to repeal.

As explained, a Court interpretation inside $\left[Q_{\min }, Q_{\operatorname{mx}}\right]$ cannot be repealed by any proposal made by the Commission. It is likely that the Commission's most preferred point is inside $\left[Q_{\min }, Q_{\max }\right]$, in which case $\left[Q_{\min }, Q_{\max }\right]$ represents the Court's discretionary power of interpretation, as depicted in Figure 4. However, it is possible that the Commission's most preferred point is outside $\left[Q_{\min }, Q_{\max }\right]$, in which case the Court' $s$ discretion is even greater. To illustrate, suppose the Commission's most preferred point, denoted $\mathrm{E}$, is larger than $Q_{\max }$. Consequently, if the Court's interpretation is: above $Q_{\max }$ and below $\mathrm{E}$, the Commission will not propose its repeal. Thus the Court's discretionary power of interpretation is represented by $\left[Q_{\min }, E\right]$. In general, the Court's discretionary power of interpretation can be written $\left[\min \left(E, Q_{\min }\right), \max \left(E, Q_{\max }\right)\right]$.

Notice that changing from unanimity to qualified majority causes the discretionary power to increase for the Commission and decrease for the Court. The change from unanimity to qualified majority is a movement towards requiring a weaker majority. In general, rules requiring weaker majorities undermine the status quo. The Court defines the status quo through interpretation of legislation. Consequently, a constitutional change requiring weaker majorities to legislate reduces the Court's power, and strengthens the power to propose legislation, which the Council enjoys.

\section{Cooperation}

Next we consider the procedure of cooperation. Under this procedure, a proposal by the Commission can be enacted by either of two routes. First, a proposal by the Commission can be enacted by a majority in Parliament and a qualified majority in the Council. If Parliament favors the proposal, the Commission's discretionary power is the same as in Figure 4. Second, a proposal opposed by a majority in Parliament can be enacted by a unanimous Council. If Parliament opposes the proposal, the Commission's discretionary power is the same as in Figure 3. To describe the Commission's discretionary power, we only need to modify Figures 3 and 4 to take account of Parliament's preferences.

Let $\mathbf{P}$ denote the proposal most preferred by a majority in Parliament, ${ }^{39}$ and let $\mathrm{P}(0)$ denote the proposal that a majority in Parliament regards indifferently relative to 0 . Any proposal by the Commission that falls in the interval $[0, P(0)]$ will command a majority in Parliament. Any proposal by the Commission that falls in the interval $[0, Q(0)]$ will command a qualified majority in the Council. Consequently, any proposal

${ }^{96}$ We assume single-peaked preferences, so that $P$ is the most preferred point of the median voter in Parliament. Alternatively, we assume cyclical preferences in Parliament with the outcome determined by an agenda setter who 
by the Commission in the interval $[0, \min (P(0), Q(0))]$ will be enacted by the first route, as depicted in Figure 5.

Any proposal by the Commission that lies above $\mathrm{P}(0)$ will be defeated by a majority in Parliament. However, the proposal will be enacted by a unanimous Council if it lies below $\mathrm{U}(0)$. Furthermore, a unanimous Council would prefer $U_{\min }$.to any proposal below $U_{-}$Consequently, any proposal by the Commission in the interval $\left[U_{\min } U(0)\right]$ can be enacted by the second route.

In sum, any proposal by the Commission will be enacted by the first or second route if it is in the interval

$$
\left\{U_{\min }, \max \{\mathrm{U}(0), \min (P(0), Q(0))\}\right]
$$

This interval describes the Commission's discretionary power. Figure 5 illustrates the case in which $\mathbf{U}(0)<\mathbf{P}(0)<Q(0)$, where the Commission's discretionary power is given by $\left[\mathrm{U}_{\min }, \mathrm{P}(\mathbf{0})\right]$.

Now consider the Court's discretionary power of interpretation. The Court's interpretation can be repealed by legislation following either of two routes. To preclude repeal, both routes must be blocked.

The first route to repeal requires a unanimous Council to override the objection of a majority in Parliament. If the Court offers an interpretation below $U_{\min }$ a unanimous Council will prefer $\mathrm{U}_{\min }$. If the Court offers an interpretation above $\mathrm{U}_{\max }$, a unanimous Council will prefer $\mathrm{U}_{\text {ax }}$. However, if the Court offers an interpretation inside the interval $\left[\mathrm{U}_{\omega_{\text {mix }}}, \mathrm{U}_{\max }\right]$, someone on the Council will object to any change. Consequently, the first route to legislative repeal is blocked in the legislature by interpretations in the interval [ $\left.\mathrm{U}_{\min }, \mathrm{U}_{\max }\right]$.

The second route to repeal requires a majority in Parliament and a qualified majority in the Council to prefer an alternative rather than the Court's interpretation. If the Court offers an interpretation inside the interval $\left[Q_{\min }, Q_{\max }\right]$, the complement of a qualified majority will object to any change. If the Court offers an interpretation outside the interval $\left[Q_{\min }, Q_{\max }\right]_{\text {, a }}$ qualified majority in the Council will favor a move towards this interval. However, a majority in Parliament will oppose the move if it is

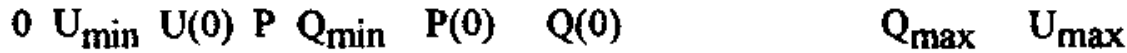

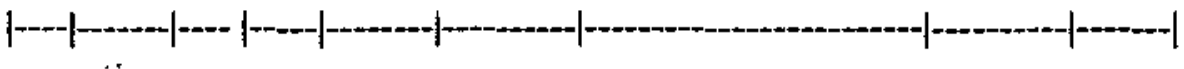

small

DIMENSION OF POLITICAL CHOICE

Commission's

Discretion 
away from $\mathrm{P}$. Consequently, repeal by the second route will be blocked if the Court's interpretation is in the interval $\left[\min \left(P, Q_{\min }\right), \max \left(P, Q_{\max }\right)\right]^{40}$

To illustrate, in Figure 5 the Parliament's most preferred point $P$ lies below $Q_{\text {min }}$. Consequently, the Court's discretionary power of interpretation is the interval above $P$ and below $Q_{\max }$, as shown.

We have shown that repeal is blocked in the legislature for Court interpretations simultaneously in the interval $\left[\mathrm{U}_{\operatorname{mix}}, \mathrm{U}_{\operatorname{mix}}\right]$ and in the interval $\left[\min \left(\mathrm{P}, \mathrm{Q}_{\min }\right), \max \left(\mathrm{P}, \mathrm{Q}_{\min }\right)\right]^{* 1}$ We must also consider the role of the Commission in blocking legislation. If the Commission prefers the Court's interpretation rather than any legislation that the legislature will enact, then the Commission will block repeal of the Court's interpretation by refusing to propose new legislation. Thus the Commission increases the Court's discretion when the latter's most preferred point is in the interval where the legislature could repeal an interpretation. The general formulation of the interval indicating the Court's discretion is relegated to a footnote. ${ }^{42}$

\title{
D. Co-Decision
}

Finally, consider the procedure of co-decision. Any proposal by the Commission will be enacted if it is preferred to the status quo by a majority in Parliament and a qualified majority in the Council. Consequently, the upper bound of the Commission's: zone of discretion is given by $\mathrm{P}(0)$ or $\mathrm{Q}(0)$, whichever is smallest. Furthermore, the

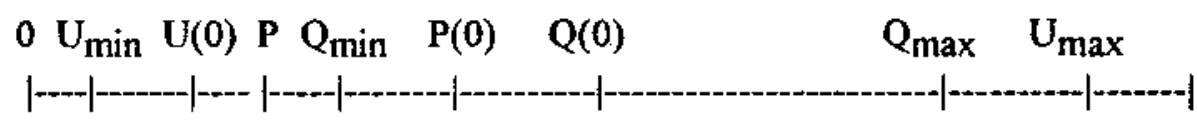

small

DIMENSION OF POLITICAL CHOICE

large

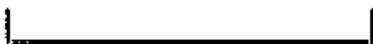

Commission's

Discretion

Court's Discretion

Fic. 6. Power under the procedure of co-decision.

\begin{abstract}
"To iltustrate, assume that $P$ is below $Q$.. If the Court offers an interpretation below $P$, then a move to $P$ will be favored by a majority in Parliament and a qualified majority in the Counsel. However, if the Court offers an interpretation in the interval $\left[P, Q_{\ldots}\right]$, Parliament will object to a move to the right, and the complement of a qualified majority will object to a move to the left.
\end{abstract}

4'Equivalendy, repeal is blocked by the legislature for interpretations in the interval

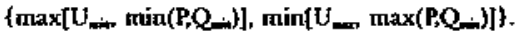

4'In general, repeal is blocked by the legislature or the Comraission for interpretations in the interval $\left[\min \left\{E_{,} \max \left\{U_{-}, \min \left(P_{,} Q_{\min }\right)\right]\right\}, \max \left\{E_{,} \min \left(U_{-m} \max \left(P_{,} Q_{\min }\right)\right\}\right\}\right]$

To illustrate, suppose the Commission's most preferred point, denoted $E$, is larger than max $\left(P, Q_{-\alpha}\right)$. Consequently, if the Court's interpretation is above $\max \left(P, Q_{m}\right)$ and below $\mathrm{E}$, the Commission will not propose its repeal. 


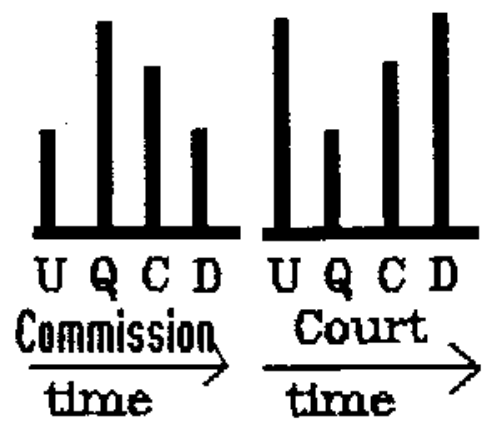

Procedure:

$u=$ congult+unanimity

$q=$ consult + qualfled

majority

$c=$ cooperation

$d=c o-$ decision

F1G. 7. Shifting power with time in EC.

Commission's proposal cannot be amended provided that it is not below $U_{\min }$ and $P$. The Commission's discretionary power of proposal can be represented by $\left[\min \left(\mathrm{U}_{\min }, \mathrm{P}\right), \min (\mathrm{P}(\mathbf{0}), \mathrm{Q}(0))\right]$.

In order for an interpretation by the Court to be repealed under the co-decision procedure, an alternative must exist that is preferred by the Commission, a majority in Parliament, and a qualified majority in the Commission. The lower bound on the Court's power of interpretation is given by the smallest of $P, Q_{\text {min }}$ and $E$, whereas the upper bound is given by the largest of $P, Q_{\max }$, and $\mathbf{E}$. Thus the Court's discretionary power of interpretation can be denoted $\left[\min \left(P, Q_{\text {mix }}, E\right), \max \left(P, Q_{\text {max }}, E\right)\right]$, as illustrated in Figure 6.

\section{Summary and Conclusion}

The democratization of the European Community takes two forms: Council majoritarianism and bicameralism. As the process advances, more kinds of legislation require weaker majorities in the Council and a majority in Parliament. The obvious consequence is a loss of veto power by small nations in the Council and an increase in the power of Parliament. The not-so-obvious consequence is a shift in power between Commission and Court, as depicted in Figure 7. The Commission's discretionary power, created by its exclusive power to propose legislation, increases with Council majoritarianism and decreases with bicameralism. In contrast, the discretionary power of the Court, created by its final power to interpret legislation, changes in the opposite direction from the Commission.

We conclude by offering some comments on the institutional limitations of our model ${ }^{43}$ and some remarks on its normative implications. Our model assumes that the Commission exercises raw power by making take-it-or-leave-it proposals. In reality, the Commission proceeds by bargaining, and skillful bargainers seldom exercise their raw power. However, raw power often guides bargaining by defining the relative strength of the parties, in light of which they calibrate their mutual concessions. Consequently, our analysis will provide the foundation for a bargaining model, which, if developed, would be more accurate and complex.

"As for formal limitations, our model assumes a single dimension of choice, but we believe that it generalizes to a dimensions. The ctucial assumption is that institutions reveal consistent preference orderings in n dimensions. 
Unlike the Commission, the Court does not explicitly bargain with anyone. Whether it bargains implicitly is a matter of conjecture and dispute. In any case, the Court strives for a spirit of cooperation with other government institutions by showing restraint in exercising its discretionary power. Indeed, judges typically articulate principles of interpretation that circumscribe their role in making law. Even so, we believe that the actual behavior of courts often reflects their discretionary power as developed in this article. This belief can be tested in principle by correlating the extent of judicial lawmaking and the discretionary power of courts as they change through time and across jurisdictions.

We assume that Commission, Council, Parliament, and Court reveal stable preferences, but we have said nothing about their sources. Instead of treating the preferences of Europe's decision-making institutions as given, it would be better to explain them. An explanation would recognize links between these institutions, which make their preferences interdependent. To illustrate, the political party that controls a national. government may dispatch a minister to the Council, appoint a judge to the Court, and nominate someone to run for Parliament.

Another important extension of our model concerns its normative implications. Gradual changes in Europe's constitution should not escape scrutiny just because they are labeled "democratization." Scrutiny reveals several concerns. First, the movement towards democracy has complex effects on small nations. Europeans typically believe that the changes are undermining the protection of small nations against unwanted legislation. However, this belief may be mistaken. The general belief is correct that Council majoritarianism undermines the protection of small nations against unwanted legislation. Any move to weaken the supermajority required for the Council to enact legislation increases the size of the submajority coalition that small nations need to obstruct legislation. However, bicameralism has the opposite effect. Bicameralism protects minorities more than unicameralism because it is harder for any group to obtain a majority in two houses rather than in one house. ${ }^{44}$ The movement towards majority rule has weakened the first form of protection, but the movement towards bicameralism has strengthened the second form. Since democratization thus far takes the form of majoritarianism and bicameralism, it is unclear whether the small nations enjoy less protection or more. ${ }^{45}$

Second, we proved that bicameralism increases the Court's discretionary power. More discretionary power of the Court will result in more European judge-made law and less legislation. This change is not self-evidently good. An important question for discussion is whether judge-made law or legislation will be more efficient in Europe,

\footnotetext{
"Each group in soxiety usually has its nembers distributed differently in the jurisdictions of the lower house and the upper house. To illustrate fiom the United States, each state has two "senators" (upper house) elected in the state as a whole and several "representatives" (lower house) elected by districts within the state. One party may have a majority in the state, thus electing the two senators to the upper house. but not have a majority in a majority of the districts, thus electing less than $50 \%$ of the representatives to the lower house. The analysis is different under a system of proportional representation See Saul Levmore, "Bicameralism: When Are Two Decisions Better Than One?," 12 Inll. Rev. $L$ \& Econ 145 (1992).
}

${ }^{15}$ There is another kind of protection that small states enjoy. In cooperative ventures, conformity to collective decisions tends to be greater on the part of large memhers, whereas small members are more tikely to "cheat" on the agreement. This prediction applies to business cartels such as OPEC or to international organizations such as NATO. 
especially for acts aimed at establishing the Internal Market. ${ }^{46}$ So far, the Commission, Parliament, and Court have tended to ally against the Council in promoting European power and democracy. In time, however, the Commission and the Court may find themselves in opposition because the former's power is diminished by bicameralism and the latter's power is increased by it.

Third, strengthening the power of Parliament relative to the Council may not be the most urgent democratic reform. In most democracies, the executive is elected directly (president) or indirectly (prime minister), whereas the Commission is appointed. Democratizing Europe's executive requires electing the head of the Commission or relocating the power to propose legislation in the legislature. Such a change would affect the power of the Court in ways predictable from this paper. If the head of the Commission were elected, proposals to repeal the Court's interpretation of the law could be vetoed by the executive or the two houses of the legislature, as under the co-decision procedure. Consequently, the Court would retain a similar measure of discretionary power that it now enjoys under the co-decision procedure. However, if the power to propose legislation were relocated in the legislature, the independent vetoes on fresh legislation would fall from three to two, thus diminishing the discretionary power of the Court.

So far we have said nothing about the people whom the members of Council and Parliament represent. A simple connection is formed by the "median rule." If each member of the Council has the same preferences as the median voter in his nation, then the protection of small nations is equivalent to the protection of the median voter in them. ${ }^{18}$ If Parliament has the same preferences as the median voter in Europe, then increasing the power of Parliament creates a tendency for European laws to converge upon the center of the political spectrum. By such theories we begin to glimpse the destination towards which Europe has apparently embarked in its constitutional reforms.

\footnotetext{
"There is a large literature on the efficiency of the judge-made law and legislation. An overview of the former is in Cooter, "Markets for Norms: Evolution of the Common Law Revisited" (John M. Olin Working Papers in Law and Economics, School of Law, University of California at Berkeley, \#94-1, 1994). An overview of the batter is in Cooter, "Collective Choice Theory: A Review" (John M. Olin Working Papers in Law and Economica, School of Law, University of California at Berkeley, *91-4, Fall 1991).
}

${ }^{17}$ The median rule was invented by Duncan Black, The Theory of Commiltets and Elections (Boston: Kluwer Academic, 1987).

"The minorities within each nation could be protected by a bill of individual rights, and possibly. a bill of group rights for minorities. Alternatively, proportional representation could be used to weaken the majority's control on representatives. 